IRTERDEPEADERCE 
This page intentionally left blank 
MEANING SYSTEMS

\section{SERIES EDITORS}

Bruce Clarke and Henry Sussman

EDITORIAL BOARD

Victoria N. Alexander, Dactyl Foundation for the Arts and Humanities

Erich Hörl, Ruhr University Bochum

John H. Johnston, Emory University

Hans-Georg Moeller, Philosophy and

Religious Studies Program, University of

Macau, China

John Protevi, Louisiana State University

Samuel Weber, Northwestern University 
This page intentionally left blank 


\title{
I ITERDEPERDERCE
}

Biology and Beyond

\author{
KRITI SHARMA
}

Fordham University Press : New York 2015 
All rights reserved. No part of this publication may be reproduced, stored in a retrieval system, or transmitted in any form or by any means-electronic, mechanical, photocopy, recording, or any other-except for brief quotations in printed reviews, without the prior permission of the publisher.

Fordham University Press has no responsibility for the persistence or accuracy of URLs for external or third-party Internet websites referred to in this publication and does not guarantee that any content on such websites is, or will remain, accurate or appropriate.

Fordham University Press also publishes its books in a variety of electronic formats. Some content that appears in print may not be available in electronic books.

Visit us online at www.fordhampress.com.

Library of Congress Cataloging-in-Publication Data

Sharma, Kriti.

Interdependence : biology and beyond / Kriti Sharma. pages $\mathrm{cm}$. - (Meaning systems)

Summary: "From biology to economics to information theory, the theme of interdependence is in the air, framing our experiences of all sorts of everyday phenomena. Indeed, the network may be the ascendant metaphor of our time. Yet precisely because the language of interdependence has become so commonplace as to be almost banal, we miss some of its most surprising and far-reaching implications" — Provided by publisher.

Includes bibliographical references and index.

ISBN 978-0-8232-6552-7 (hardback) ISBN 978-0-8232-6553-4 (paper)

I. Autonomy (Philosophy) 2. Biology-Philosophy.

I. Title.

B808.67.S53 2015

III-dc23

2014045376

Printed in the United States of America

I7 I6 I5 5432 I

First edition 
To Om and Jyoti Sharma, generous and loving parents.

To Rulia Ram Sharma, Kanta Sharma, Giridhari Lal Nagar, and Raksha Nagar, cherished and respected grandparents.

And to all the ancestors upon whom this life depends. 
This page intentionally left blank 